\title{
Sistem Informasi Perpustakaan Berbasis Web di SMK Fatahillah Cileungsi
}

\section{Web-based Library Information System at SMK Fatahillah Cileungsi}

\author{
Ade Ajie Ferizal, Mohamad Anas Sobarnas*, Djoko Nursanto \\ *Program Studi Teknik Informatika, Sekolah Tinggi Teknologi Muhammadiyah Cileungsi-Indonesia \\ * Jl. Anggrek No.25 Komplek Perum PTSC, Cileungsi, Bogor, Jawa Barat-Indonesia 16820
}

\begin{tabular}{l} 
Informasi Artikel \\
\hline Article History: \\
Submission: $30-11-2021$ \\
Revised: $24-12-2021$ \\
Accepted: 24-12-2021 \\
Kata Kunci: \\
Perpustakaan; Website, \\
MySql; RAD; Bootstrap \\
Keywords: \\
Library; Website; MySql,RAD; \\
Bootstrap \\
* Korespondensi: \\
Mohamad Anas Sobarnas \\
anassobarnas87@gmail.com
\end{tabular}

\begin{abstract}
Abstrak
Perpustakaan sekolah merupakan sebuah fasilitas sekolah dalam mengelola penyediaan buku ajar dan buku-buku pendamping terkait ilmu pengetahuan umum, teknologi dan ilmu terapan lainnya. Fungsi perpustakan merupakan suatu hal yang sangat penting dalam membantu siswa-siswi menyediakan akan kebutuhan buku pelajaran dan buku pendamping dengan cara mudah dan murah. Namun dalam kenyataannya selama ini masih banyak kendala terkait dalam pengelolaannya, diantaranya bagaimana mengontrol jumlah stok, menghitung jumlah peminjam, jumlah kembali dan registrasi dalam peminjaman. Kondisi pengelolaan perpustakaan di SMK Fatahillah Cileungsi masih dilakukan secara manual sehingga memungkinkan terjadi kesalahan dalam sirkulasi peminjaman dan pengembalian buku karena data-data yang belum terdokumentasi dengan baik sehingga pelayanan menjadi kurang maksimal. Tujuan dari penelitian dalam mengatasi permasalahan diatas dengan membuat rancangan aplikasi sistem peminjaman buku berbasis web, dimana sistem yang dirancang ini biasa melakukan registrasi peminjaman secara online, pengontrolan stok buku, membuat list peminjam, list pengembalian dan pembuatan laporan. Metode pengembangan aplikasi perpustakaan berbasis web ini menggunakan metode Rapid Application Development (RAD), bahasa pemrograman PHP, database MySql pada Framework Bootstrap. Setelah di lakukan perancangan dan pengujian aplikasi ini dapat membantu pengelolan perpustakaan menjadi lebih baik sehingga dapat meningkatkan pelayanan pengelolaan perpustakaan di SMK Fatahillah Cileungsi.
\end{abstract}


based book lending system application, where the system designed is used to register online loans, control book stock, create borrower lists, return lists and make reports. This web-based library application development method uses the Rapid Application Development (RAD) method, the PHP programming language, the MySql database on the Bootstrap Framework. After designing and testing this application, it can help better library management so that it can improve library management services at Fatahillah Vocational School Cileungsi.

\section{PENDAHULUAN.}

Sebuah perpustakaan merupakan salah satu sumber belajar siswa-siswi yang harus dimiliki oleh sebuah sekolah atau perguruan tinggi. Karena siswa-siswi akan dengan mudah dalam mencari informasi pembelajaran atau terkait ilmu pengetahuan melalui perpustakaan. Dapat diartikan pula bahwa perpustakaan merupakan sebuah pengembangan koleksi, pengelolaan koleksi, bagian pelayanan pengguna dan bagian pemeliharaan sarana dan prasarana[1].

Permasalahan yang dijumpai di perpustakaan SMK Fatahillah Cileungsi terletak pada cara yang digunakan perpustakaan untuk menangani peminjaman dan pengembalian buku yakni masih dilakukan secara manual dengan melakukan pencatatan pada kartu pinjam. Cara pengelolaan yang masih manual tersebut menyebabkan kesulitan dalam pengontrolan stok buku, daftar peminjaman buku, daftar pengembalian buku dan pembuatan laporan.

Dalam hal pembuatan laporan perpustakaan petugas harus menghitung secara manual terkait buku yang dipinjam, yang dikembalikan selama satu bulan tentunya hal ini menjadi tidak efektif sehingga ini kondisi itu menyebabkan banyak waktu yang terbuang untuk mengerjakan sebuah laporan bulanan peminjaman buku perpustakaan.

Dalam pemecahan masalah tersebut diatas, penelitian ini bertujuan untuk melakukan perancangan sebuah sistem informasi terhadap perpustakaan SMK Fatahillah Cileungsi yang berbasis web dengan tujuan supaya memudahkan staf dalam pengelolaan perpustakaan dan memudahkan akses siswa dalam registrasi peminjaman buku karena dilakukan bisa secara online.

Dalam penelitian-penelitian sebelumnya terkait dengan perancangan sistem aplikasi perpustakaan sebagai referensi penulis dalam penelitian ini, diantaranya sudah dilakukan penelitian yang menghasilkan sistem aplikasi perpustakaan berbasis web yang merubah dari cara manual menjadi menggunakan sistem komputer berbasis web untuk pengelolaan perpustakaan di SMK Citra Negara Depok[2].

Adapaun tujuan dari penelitian yaitu mengatasi permasalahan terkait registrasi peminjaman buku kepada perpustakaan dari bersifat offline menjadi online, pengontrolan stok buku, membuat list peminjam, list pengembalian dan pembuatan laporan nantinya bisa di kontrol dengan aplikasi sistem perpustakaan berbasis web.

\section{TINJAUAN PUSTAKA}

\subsection{Sistem}

Sistem merupakan suatu kesatuan objek yang saling keterkaitan dan ketergantungan serta saling mendukung secara menyeluruh untuk tujuan tertentu secara efektif dan efisien[3]

\subsection{Informasi}

Informasi merupakan kumpulan fakta atau data yang telah diproses sehingga sedemikian rupa menjadi suatu yang mudah dimengerti dan bermanfaat untuk penerimanya[4]. 
2.3 Sistem informasi perpustakaan

Menurut[2] suatu aplikasi sistem terkait perpustakaan yang merupakan suatu sistem yang saling terkait dan bekerja sama secara sistematis dalam mengelola administrasi dan operasional perpustakaan serta menghasilkan output laporan yang efektif dan berguna bagi manajemen perpustakaan.

2.4 Web

World Wide Web (WWW) merupakan suatu layanan jaringan data yang didapat oleh pengguna komputer yang terhubung ke internet. Layanan informasi yang dapat oleh pengguna yang terhubung ke internet berupa informasi yang berguna baik dan tidak baik sekalipun, yang bersifat gratis dan komersial. Web bisa diartikan pula yaitu kumpulan halaman-halaman WWW (World Wide Web) atau juga dikenal dengan WEB, dimana Web adalah salah satu layanan yang didapat oleh pemakai komputer yang terhubung ke internet dapat mengakses situs-situs yang dapat menampilkan informasi teks, gambar, audio, video baik secara statis dan dinamis yang saling terkait yang menghubungkan jaringanjaringan[5].

2.5 Bahasa PHP

Bahasa PHP merupakan bahasa server-side script artinya bahasa php merupakan bahasa pemrograman yang hanya bisa di baca kode program di sisi server saja. Penggunaan bahasa pemrograman PHP memungkinkan pengembang membuat aplikasi berbasis web secara lebih dinamis sehingga dalam mengelola dan perbaikan bias menjadi lebih mudah, efektif dan efisien[6]. Bahasa pemrograman php merupakan bahasa server-side scripting yang dapat disatukan dengan HTML dalam pembuatan Web dinamis[7].

2.6 MySQL

MySQL merupakan salah satu sistem manajemen database relasional (RDBMS) yang berbasis query yang bersifat open source dengan model client server. MySql walaupun merupakan suatu aplikasi DBMS yang open source tetapi memiliki performance yang cepat, reliable dan mudah digunakan. Sekarang ini dengan memiliki keunggulan yang cukup andal banyak digunakan oleh pengembang software untuk membuat proyek aplikasi[8]. MySql merupakan jenis database server yang banyak digunakan dalam pembuatan web dalam pengolahan database webnya[9].

2.7 Bootstrap

Bootstrap merupakan kerangka kerja dengan CSS yang digunakan untuk membangun situs web front-end. Bootsrtap biasa digunakan untuk kebutuhan grafis pada tampilan visual dari aplikasi website[10]. Bootstrap merupakan suatu library dari berbagai fungsi yang terdapat pada framework CSS yang dirancang khusus untuk pengembangan front-end website. Selain menggunakan framework CSS juga menyediakan HTML, CSS dan Javascript sehingga memudahkan dalam pengembangan[11].

\section{METODE}

Rapid Application Development (RAD) merupakan salah satu metode pengembangan perangkat lunak yang berfokus pada pengembangan aplikasi secara cepat melalui konsep pengulangan dan feedback secara berulang [12]. Dimana RAD merupakan suatu pendekatan berorientasi objek terhadap pengembagan sistem yang mencakup suatu pengembangan dari perangkat-perangkat lunak[13]. 


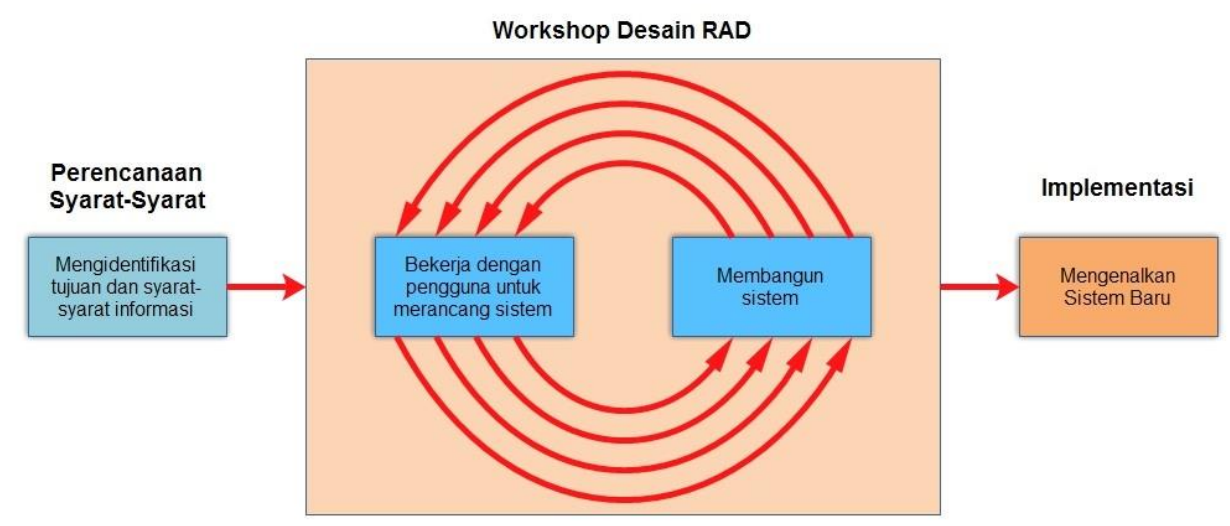

Gambar 1. Rapid Application Development (RAD)

Gambar 1 dalam pengembangan menggunakan metode RAD, langkah awal yaitu dengan menyiapkan persyaratan terkait kebutuhan sistem, langkah selanjutnya perancangan sistem menggunakan siklus berulang-ulang dalam merancang sampai menghasilkan aplikasi yang sesuai dengan perancangan, selanjutnya implementasi dari sistem baru.

Adapun tahapan-tahapan dalam pengembangan menggunakan metode RAD yaitu requirement planning, design workshop dan implementation.

a. Tahapan requirements planning

Pada tahapan ini user dan penganalisis bertemu untuk mengidentifikasi tujuan-tujuan aplikasi dan mengidentifikasi syarat informasi yang timbul dari tujuan tersebut. Orientasi pada tahapan ini adalah pemecahan masalah tetapi berfokus pada tujuan perusahaan.

b. Tahapan workshop desain RAD.

Pada tahapan ini merupakan tahapan dalam merancang dan memperbaiki yang digambarkan di workshop. Workshop ini bisa dilakukan berkali-kali tergantung kebutuhan dan ukuran aplikasi yang akan dikembangkan. Selama workshop pengguna memberikan respon sebagai model atau prototype. dari model yang sedang dibuat, sedangkan penganalisis memperbaiki modul yang dirancang berdasarkan respon pengguna[14].

c. Tahapan implementasi.

Pada tahapan implementasi ini penganalisis bekerjasama dengan pengguna secara intens dalam workshop dan merancang terkait pada aspek-aspek bisnis dan non teknis dari perusahaan. Setelah aspek-aspek tersebut disetujui dan sistem-sistem diujikan, selanjutnya sistem baru akan disampaikan pada perusahaan.

\section{HASIL DAN PEMBAHASAN}

proses yang ada pada perpustakaan SMK Fatahillah Cileungsi. Dimana saat proses melakukan pendaftaran anggota, pencarian jenis buku, proses peminjaman buku, pengembalian buku dan laporan masih kurang efektif karena memerlukan waktu yang lama dalam pelayanannya. Siswa - siswa SMK Fatahillah Cileungsi yang ingin mendaftar menjadi anggota perpustakaan terlebih dahulu harus datang ke perpustakaan. Kemudian pada saat proses peminjaman anggota harus mencari buku pada lemari - lemari buku yang berisikan berbagai macam jenis buku sehingga menyulitkan anggota dalam pencarian jenis buku yang akan dipinjam, selain itu pula anggota tidak mengetahui informasi tentang jumlah ketersediaan buku, update buku baru. Selain itu, petugas juga kesulitan dalam mengumpulkan data, dikarenakan pada proses pencatatan informasi buku, anggota, peminjaman, pengembalian yang dilakukan pada pembukuan pencatatan perpustakaan. 


\subsection{Use case diagram}

Use case diagram merupakan gambaran dari interaksi sistem dengan lingkungannya seperti terlihat pada gambar 2 .

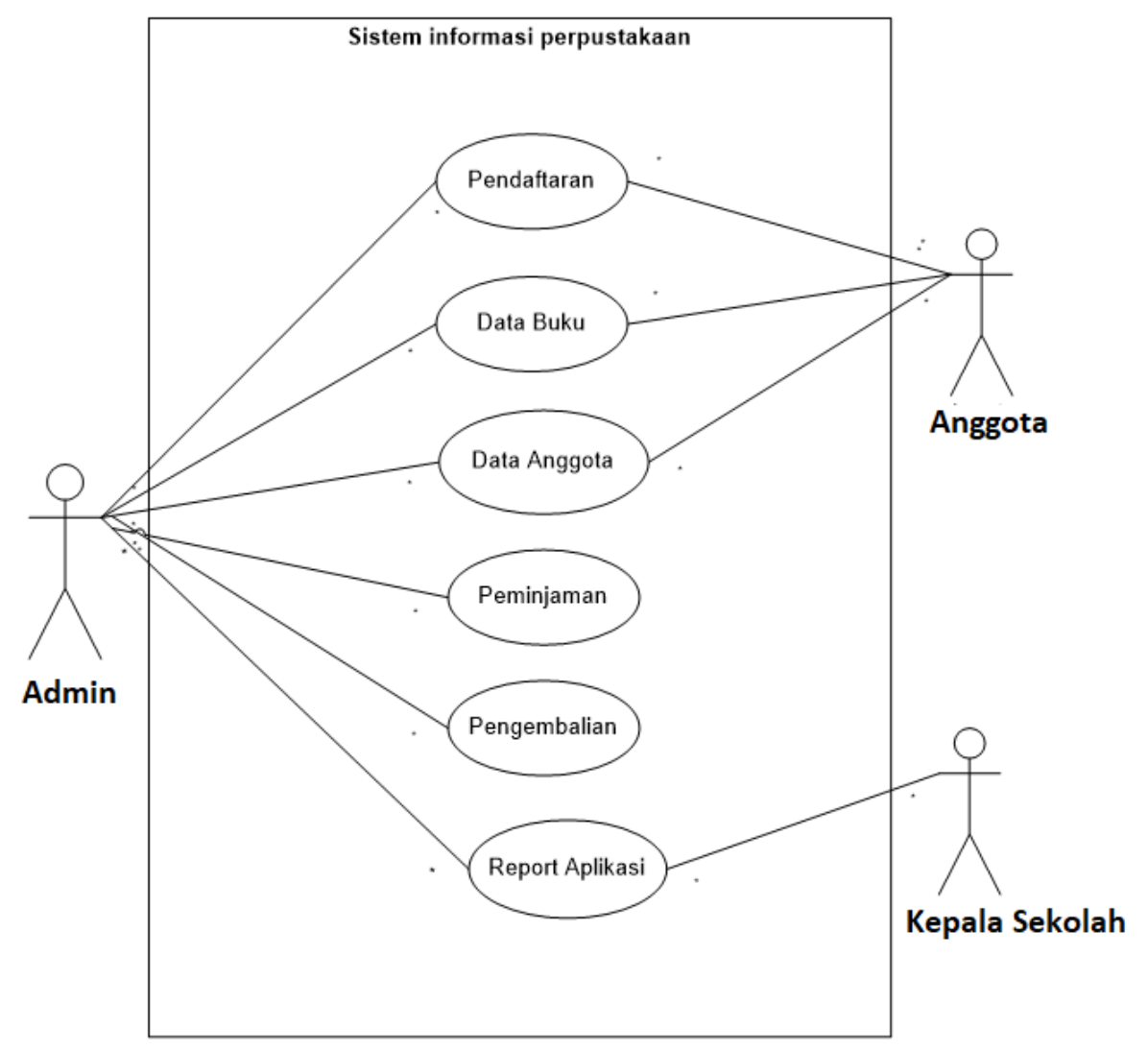

Gambar 2. Use Case Diagram Sistem yang dirancang

Gambar 2 menjelaskan, 1) Aktor admin berinteraksi dengan sistem terkait, pendataan, data buku, data anggota, peminjaman, pengembalian dan laporan. 2) Aktor anggota berinteraksi dengan sistem terkait pendaftaran menjadi anggota, data buku dan data anggota. 3) Aktor kepala sekolah berinteraksi sistem terkait dengan laporan.

Use case diagram merupakan suatu urutan interakasi yang saling keterkaitan antara sistem dengan pelaku sistem atau aktor[15]. Aktor dalam use case bisa berupa orang, peralatan atau sistem lain yang berinteraksi dengan sistem yang sedang dirancang.

\subsection{Activity diagram}

Diagram activity pemodelan yang dilakukan pada suatu sistem dan menggambarkan aktivitas sistem berjalan[16], activity diagram menjelaskan sebuah alur proses kerja didalam program yang sedang dirancang. Alur atau aktivitas ini dapat berupa menu-menu atau proses bisnis yang terdapat didalam sistem tersebut. Activity diagram yang lainya terdiri dari activity pendaftaran anggota, activity peminjaman buku, activity pengembalian buku seperti pada gambar 3.

\subsection{Class diagram}

Class Diagram (diagram kelas) merupakan diagram paling umum dipakai di semua pemodelan berorientasi objek. Class Diagram menggambarkan serta deskripsi atau penggambaran dari class, atribut, dan objek disamping itu juga hubungan satu sama lain seperti pewarisan, containment, asosiasi dan lainnya[17]. Berikut ini adalah class diagram pada 
perancangan sistem informasi perpustakaan berbasis web pada SMK Fatahillah Cileungsi seperti pada gambar 4 .

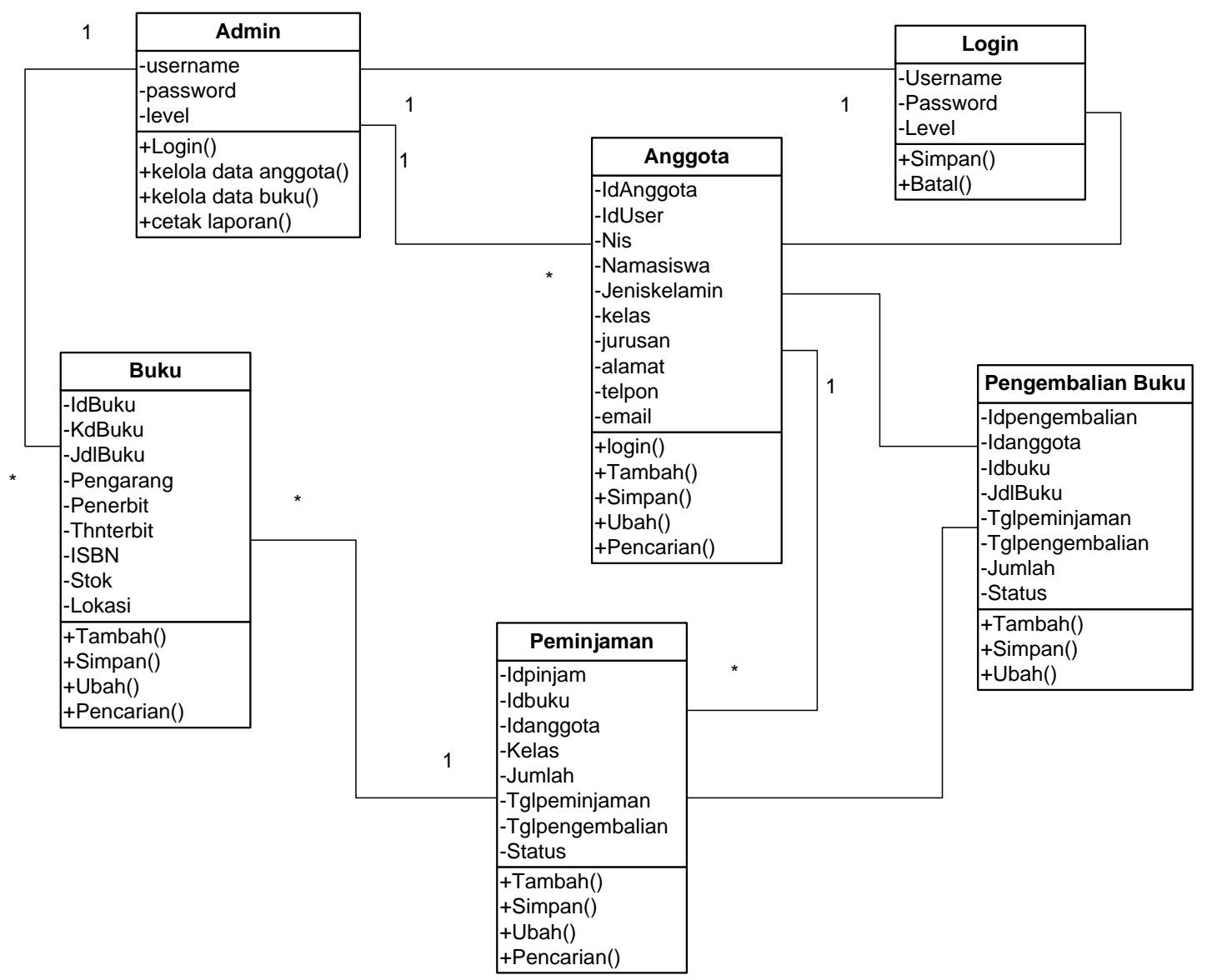

Gambar 4. Rancangan class diagram

Gambar 4 menjelaskan, 1) Seorang admin akan mempunyai relasi class dengan Login, 2) Banyak anggota mempunyai hubungan relasi dengan class admin, login, peminjaman buku dan pengembalian buku.

\subsection{Tampilan GUI}

Implementasi pada sistem informasi perpustakaan berbasis Web di SMK Fatahillah Cileungsi terdiri dari form halaman utama, form pendaftaran, form peminjaman, form pengembalian, untuk fungsi dari masing-masing form sebagai berikut:

a) Halaman utama

Halaman utama dari aplikasi perpustakaan SMK Fatahillah Cileungsi, setelah membuka Website sistem informasi perpustakaan, di dalam halaman utama terdapat menu beranda, pendaftaran dan login.

b) Form pendaftaran anggota

Form ini berfungsi untuk proses pendaftaran siswa sebagai anggota perpustakaan. Berikut adalah tampilan dari form pendaftaran anggota.

c) Form peminjaman buku

Form peminjaman ini berfungsi untuk mengelola data peminjaman buku pada perpustakaan seperti pada gambar 5 . 


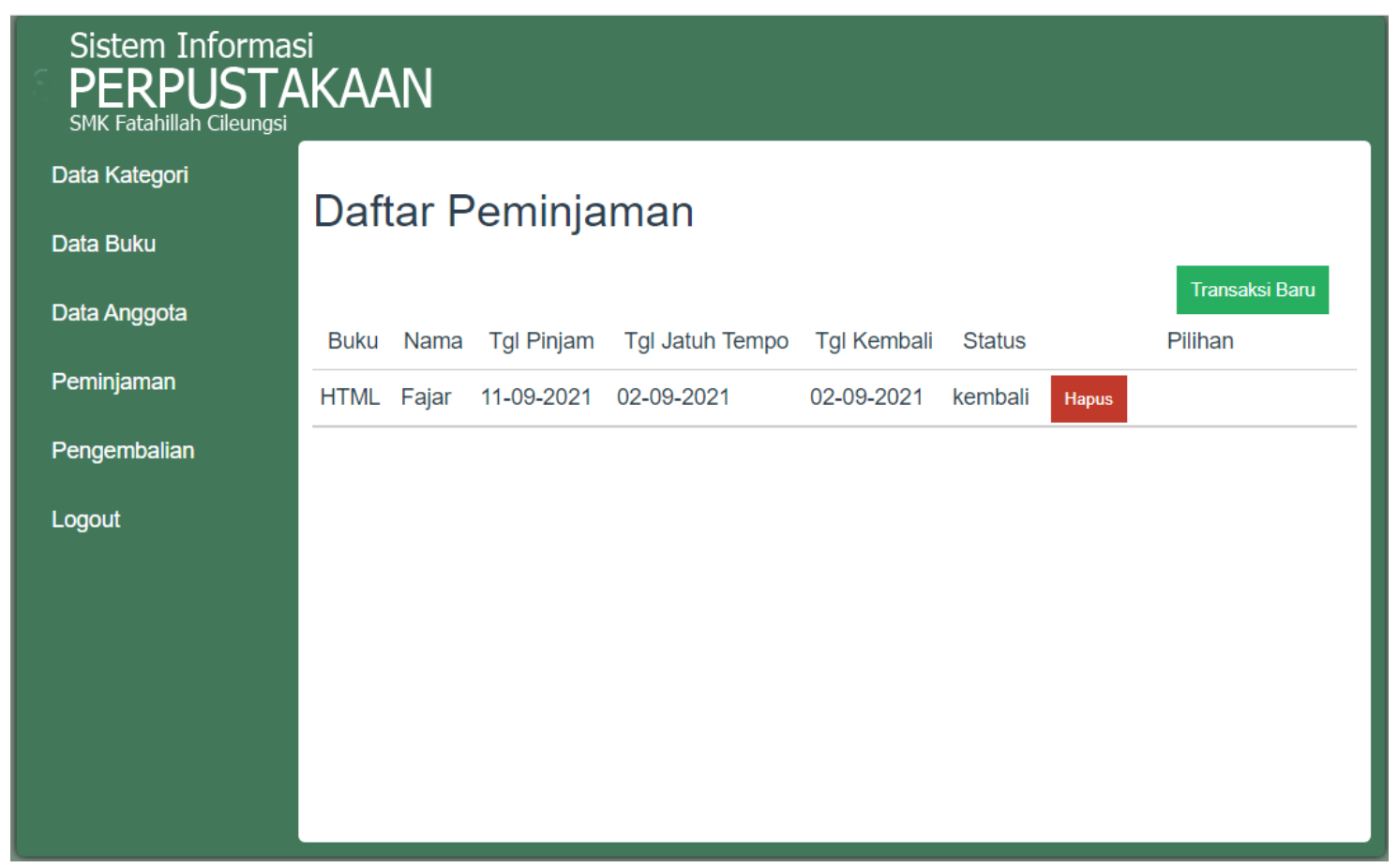

Gambar 5. Tampilan menu peminjaman buku

d) Form pengembalian buku

Form ini berfungsi untuk menambahkan data pengembalian buku apabila anggota ingin mengembalikan buku yang dipinjam.

\subsection{Pengujian sistem}

Dalam pengujian sistem aplikasi yang dirancang ini menggunakan metode Black Box testing, dimana pengujian software aplikasi dengan menitik beratkan pada fungsi dari aplikasi tersebut, adapun item yang diujikan terdiri pada form sebagai berikut.

a) Pengujian fungsi Login

Tabel 1. Pengujian login

\begin{tabular}{|c|c|c|c|c|c|}
\hline No & $\begin{array}{l}\text { Skenario } \\
\text { Pengujian }\end{array}$ & Test Case & $\begin{array}{l}\text { Hasil Yang } \\
\text { Diharapkan }\end{array}$ & $\begin{array}{c}\text { Hasil } \\
\text { Pengujian }\end{array}$ & Kesimpulan \\
\hline 1 & $\begin{array}{l}\text { Mengosongkan } \\
\text { Semua Isian Data } \\
\text { login pada login } \\
\text { admin, kemudian } \\
\text { klik tombol login }\end{array}$ & $\begin{array}{l}\text { Username: } \\
\text { "kosong" } \\
\text { Password: } \\
\text { "kosong" }\end{array}$ & $\begin{array}{l}\text { Sistem Akan } \\
\text { Menolak akses } \\
\text { login dan sistem } \\
\text { akan menampilkan } \\
\text { pesan "lengkapi } \\
\text { form yang ada!" }\end{array}$ & $\begin{array}{c}\text { Sesuai } \\
\text { harapan }\end{array}$ & Valid \\
\hline 2 & $\begin{array}{l}\text { Hanya Mengisi } \\
\text { Password dan } \\
\text { mengosongkan } \\
\text { username, } \\
\text { kemudian klik login }\end{array}$ & $\begin{array}{l}\text { Username: } \\
\text { "kosong" } \\
\text { Password: } \\
\text { admin }\end{array}$ & $\begin{array}{l}\text { Sistem akan } \\
\text { menolak login dan } \\
\text { sistem akan } \\
\text { menampilkan } \\
\text { pesan "lengkapi } \\
\text { form yang ada!" }\end{array}$ & $\begin{array}{c}\text { Sesuai } \\
\text { harapan }\end{array}$ & Valid \\
\hline
\end{tabular}


3 Menginputkan

Dengan kondisi salah satu data benar dan salah satu lagi salah

4 Menginput data pada form login dengan benar

\begin{tabular}{|c|c|c|}
\hline $\begin{array}{l}\text { Username: } \\
\text { admin } \\
\text { Password: } \\
\text { "salah" }\end{array}$ & $\begin{array}{l}\text { Sistem akan } \\
\text { menolak akses } \\
\text { login dan } \\
\text { menampilkan } \\
\text { pesan "username } \\
\text { atau password yang } \\
\text { anda masukan } \\
\text { salah!" }\end{array}$ & $\begin{array}{c}\text { Sesuai } \\
\text { harapan }\end{array}$ \\
\hline $\begin{array}{l}\text { Username: } \\
\text { admin } \\
\text { Password: } \\
\text { admin }\end{array}$ & $\begin{array}{l}\text { Sistem menerima } \\
\text { akses login dan } \\
\text { kemudian } \\
\text { menampilkan } \\
\text { dashboard admin }\end{array}$ & $\begin{array}{c}\text { Sesuai } \\
\text { harapan }\end{array}$ \\
\hline
\end{tabular}

b) Pengujian form peminjaman buku

Tabel 2. Pengujian permintaan buku

\begin{tabular}{|c|c|c|c|c|c|}
\hline No & $\begin{array}{c}\text { Skenario } \\
\text { Pengujian }\end{array}$ & Test Case & $\begin{array}{c}\text { Hasil Yang } \\
\text { Diharapkan }\end{array}$ & $\begin{array}{c}\text { Hasil } \\
\text { Pengujian }\end{array}$ & Kesimpulan \\
\hline 1 & $\begin{array}{l}\text { Mengosongkan } \\
\text { Semua form input } \\
\text { peminjaman buku } \\
\text { kemudian klik } \\
\text { tombol simpan }\end{array}$ & $\begin{array}{l}\text { Idanggota: } \\
\text { "kosong" } \\
\text { Idbuku: } \\
\text { "kosong" } \\
\text { Tglpinjam: } \\
\text { "kosong" } \\
\text { Tglkembali: } \\
\text { "kosong" } \\
\text { Status: } \\
\text { "kosong" }\end{array}$ & $\begin{array}{l}\text { Sistem Akan } \\
\text { Menolak ases } \\
\text { simpan data } \\
\text { menampilkan } \\
\text { pesan "Lengkapi } \\
\text { form yang ada!" }\end{array}$ & $\begin{array}{c}\text { Sesuai } \\
\text { harapan }\end{array}$ & Valid \\
\hline 2 & $\begin{array}{l}\text { Hanya mengisi } \\
\text { Idanggota saja } \\
\text { kemudian klik } \\
\text { tombol simpan }\end{array}$ & $\begin{array}{l}\text { Idabggota: } \\
\text { k0213812 } \\
\text { Idbuku : } \\
\text { "kosong" } \\
\text { Tglpinjam: } \\
\text { "kosong" } \\
\text { Tglkembali: } \\
\text { "kosong" } \\
\text { Status: } \\
\text { "kosong" }\end{array}$ & $\begin{array}{l}\text { Sistem akan } \\
\text { menolak login dan } \\
\text { sistem akan } \\
\text { menampilkan } \\
\text { pesan "lengkapi } \\
\text { form yang ada!" }\end{array}$ & $\begin{array}{c}\text { Sesuai } \\
\text { harapan }\end{array}$ & Valid \\
\hline 3 & $\begin{array}{l}\text { Hanya mengisi } \\
\text { Idanggota dan } \\
\text { idbuku saja } \\
\text { kemudian klik } \\
\text { tombol simpan }\end{array}$ & $\begin{array}{l}\text { Idabggota: } \\
\text { k0213812 } \\
\text { Idbuku: } \\
\text { "mtk009" } \\
\text { Tglpinjam: } \\
\text { "kosong" } \\
\text { Tglkembali : }\end{array}$ & $\begin{array}{l}\text { Sistem akan } \\
\text { menolak akses } \\
\text { login dan } \\
\text { menampilkan } \\
\text { pesan "username } \\
\text { atau password yang } \\
\text { anda masukan }\end{array}$ & $\begin{array}{c}\text { Sesuai } \\
\text { harapan }\end{array}$ & Valid \\
\hline
\end{tabular}


Sistem Informasi Perpustakaan Berbasis Web di SMK Fatahillah Cileungsi

$\begin{array}{lllll} & \text { "kosong" } & \text { salah !" } & \\ & \text { Status: } & & \\ & \text { "kosong" } & & \\ \text { Menginput form } & \text { Idabggota : } & \text { Data Berhasil } & \text { Sesuai } & \text { Valid } \\ \text { peminjaman dengan } & \text { k0213812 } & \text { Disimpan } & \\ \text { lengkap kemudian } & \text { Idbuku: } & & \\ \text { klik tombol simpan } & \text { "mtk009" } & & \\ & \text { Tglpinjam: 28- } & & \\ & \text { 08-2021 } & & \\ & \text { Tglkembali: } & \\ & \text { 15-08-2021 } & & \\ & \text { Status: Pinjam } & & \end{array}$

\section{SIMPULAN}

Berdasarkan penelitian yang dilakukan di SMK Fatahillah Cileungsi terkait pemecahan masalah dalam pengelolaan perpustakaan, maka setelah dilakukan perancangan sistem informasi perpustakaan berbasis web, implementasi dan pengujian sistem dapat memudahkan dalam pengelolaan data buku, data peminjam, pengembalian dan pembuatan laporan. Selain memudahkan petugas perpustakaan dalam mengelola juga memudahkan siswa-siswi dalam melakukan peminjaman buku karena dapat dilakukan secara online. Setelah dilakukan uji coba terkait dari performance aplikasi dan diujikan kepada pengguna maka aplikasi sistem informasi perpustakaan ini dapat membantu dalam pengelolaan perpustakaan di SMK Fatahillah Cileungsi.

\section{DAFTAR PUSTAKA}

[1] A. Mangnga, "Peran perpustakaan sekolah terhadap proses belajar mengajar di sekolah," Jupiter, vol. XIV, no. 1, pp. 38-42, 2015.

[2] D. D. Hutagalung and F. Arif, "Rancang Bangun Sistem Informasi Perpustakaan Berbasis Web Pada Smk Citra Negara Depok," J. Chem. Inf. Model., vol. 53, no. 9, pp. 1689-1699, 2018.

[3] R. I. Elisabet Yunaeti Angraeni, Pengantar Sistem Informasi, 1st ed. Yogyakarta: CV. Andi Offset, 2017.

[4] D. R. Prehanto, Konsep Sistem Informasi. Surabaya: Scopindo Media Pustaka, 2020.

[5] Muksin, "IJIS Indonesian Journal on Information System ISSN 2548-6438," IJIS-Indonesia J. Inf. Syst., vol. 4, no. April, pp. 69-76, 2019.

[6] H. Riyadli, A. Arliyana, and F. E. Saputra, "Rancang Bangun Sistem Informasi Keuangan Berbasis WEB," J. Sains Komput. dan Teknol. Inf., vol. 3, no. 1, pp. 98-103, 2020.

[7] P. Ritonga, "Pengertian Bahasa Pemrograman PHP menurut Para Ahli \& Pakar," bangpahmi.com, 2015. .

[8] H. Yuliansyah, P. Studi, T. Informatika, and U. Ahmad, "Perancangan Replikasi Basis Data Mysql Dengan Mekanisme Pengamanan Menggunakan Ssl Encryption," J. Inform. Ahmad Dahlan, vol. 8, no. 1, p. 102982, 2014.

[9] P. Ritonga, "Pengertian Mysql Menurut Para Ahli \& Pakar," 2015. .

[10] M. R. Adani, "Cara Menggunakan Framework Bootstrap dan Keunggulan yang Dimiliki," sekawanmedia.co.id. .

[11] F. S. Prasetyo, "Rancang bangun sistem informasi pendataan alumni pada STIE Prabumulih berbasis website," vol. 1, no. 2, pp. 26-30, 2017.

[12] D. Diyorossi, "Perancangan Sistem Informasi Perpustakaan Berbasis Web Dengan Metode 
Rapid Application Development ( Rad ) Dan Framework Css Bootstrap," Apl. Remind. Pengontrolan Perawaran Gigi Berb, 2016.

[13] W. W. Widiyanto, "Analisa Metodologi Pengembangan Sistem Dengan Perbandingan Model Perangkat Lunak Sistem Informasi Kepegawaian Menggunakan Waterfall Development Model, Model Prototype, Dan Model Rapid Application Development (Rad)," J. Inf. Politek. Indonusa Surakarta ISSN, vol. 4, no. 1, pp. 34-40, 2018.

[14] Y. D. Wijaya, "Penerapan Metode Rapid Application Development (RAD) Dalam Pengembangan Sistem Informasi Data Toko," SITECH, vol. 3, no. 2, 2020.

[15] N. Avrilia, "SISTEM INFORMASI KEARSIPAN BERBASIS WEB PADA FAKULTAS EKONOMI DAN BISNIS UNIKA ATMA JAYA JAKARTA Nuris Avrilia PENDAHULUAN Sejak jaman dahulu arsip adalah hal terpenting dalam menjaga eksistensi suatu dokumen, data , gambar ataupun tulisan . Dengan menga," vol. Vol 1, No, 2017.

[16] K. Kawano, Y. Umemura, and Y. Kano, " Field Assessment and Inheritance of Cassava Resistance to Superelongation Disease 1 ," Crop Sci., vol. 23, no. 2, pp. 201-205, 1983.

[17] D. W. T. Putra and R. Andriani, "Unified Modelling Language (UML) dalam Perancangan Sistem Informasi Permohonan Pembayaran Restitusi SPPD," J. TeknoIf, vol. 7, no. 1, p. 32, 2019. 